\title{
Self Disclosure Individu Queer Melalui Media Sosial Instagram (Studi Deskriptif Kualitatif pada Akun @ kaimatamusic)
}

\author{
Dhiya Fauziani Hediana, Septia Winduwati \\ dhiya.915160226@stu.untar.ac.id,septiaw@fikom.untar.ac.id \\ Fakultas Ilmu Komunikasi Universitas Tarumanagara, Jakarta
}

\begin{abstract}
In current digital era, the development of technology in the world are getting more advanced and rapid. The existence of new media provides an open space for individuals to convey or receive information. One of them, a Queer who see new media as a space for expression, such as self disclosure. The limited space in the public that encourages individuals queer self disclosure through digital communication in new media, namely social media Instagram. This purpose of this study is to find out how the self disclosure of one of a Queer on social media Instagram. The analysis is based on the theory of interpersonal communication with reference which according to the concept of self disclosure and social media theory. The study conducted using a qualitative descriptive approach with case study method on the Instagram account @ kaimatamusic. The findings result of this study are informant able to open up herself by sharing her work, sexual identity, ideas, activities and open attitudes to the others on an Instagram account. Even so, there are some personal information that she did not share such as romantic partners and families.
\end{abstract}

Keywords: instagram, interpersonal communication, new media, queer, self disclosure.

\begin{abstract}
Abstrak
Di era digital saat ini, perkembangan teknologi di dunia semakin maju dan pesat. Kehadiran media baru memberikan ruang keterbukaan individu untuk menyampaikan ataupun menerima informasi. Salah satunya, individu queer yang melihat media baru sebagai ruang untuk berekspresi, seperti melakukan pembukaan diri (self disclosure). Adanya keterbatasan ruang di publik yang mendorong individu queer melakukan penyingkapan diri (self disclosure) melalui komunikasi digital di media baru yaitu media sosial Instagram. Tujuan dari penelitian ini adalah untuk mengetahui bagaimana pembukaan diri salah satu individu Queer di media sosial Instagram. Analisa dilandaskan pada teori komunikasi antarpribadi dengan referensi yang mengacu pada konsep pembukaan diri (self disclosure) dan teori media sosial. Penelitian dilakukan menggunakan pendekatan deskripsi kualitatif dengan metode studi kasus pada akun Instagram @kaimatamusic. Temuan yang dihasilkan dalam penelitian ini adalah informan dapat membuka diri dengan membagikan hasil karya, identitas seksual, ide dan gagasan, aktivitas serta sikap yang terbuka dengan orang lain di akun Instagram. Meskipun demikian, ada beberapa informasi pribadi yang ia tidak bagikan seperti pasangan romantis dan juga keluarga.
\end{abstract}

Kata Kunci: instagram, keterbukaan diri, komunikasi antarpribadi, media baru, queer.

\section{Pendahuluan}

Pada era digital di masa kini, perkembangan teknologi di dunia semakin maju dan pesat, termasuk di Indonesia. Teknologi di era ini membawa revolusi baru untuk melahirkan internet. Kehadiran internet sebagai jaringan komunikasi telah 
menciptakan karakteristik komunikasi manusia yang lebih modern. Melalui kemajuan ini, aktivitas manusia kini banyak ditunjang oleh teknologi salah satunya ruang untuk berkomunikasi. Orang-orang dapat berkomunikasi dengan mudah dan jauh lebih modern dibandingkan dulu. Internet membantu memperluas ruang manusia untuk berkomunikasi tanpa hambatan jarak dan waktu.

Kehadiran media baru membuat interaksi menjadi lebih terbuka dan bebas. Media baru memberikan keterbukaan individu untuk menyampaikan ataupun menerima informasi. Interaksi yang dibentuk melalui kehadiran media baru, membantu memberikan akses luas dalam hubungan antarindividu. Hal ini mendasari individu untuk menyampaikan informasi tentang dirinya dengan individu lain agar komunikan dapat menerima dan memahami informasi yang dimiliki oleh masingmasing individu. Hal ini berkaitan dengan pembukaan diri. Pembukaan diri atau Self disclosure merupakan jenis komunikasi, menyampaikan informasi tentang diri individu yang biasanya disembunyikan dari orang lain (DeVito, 2011). Keterbukaan diri (self disclosure) merupakan salah satu faktor yang dapat menentukan keberhasilan individu dalam melakukan interaksi sosial (Gainau, 2017).

Berbagai macam aktivitas komunikasi di dalam hubungan antar individu berkembang secara online, termasuk perilaku dalam keterbukaan diri (Loisa, Riris \& Setyanto, Yugih, 2014). Indonesia masih mengalami polemik mengenai isu keberagaman, terutama terkait isu LGBTQ+. Dikutip dari website medium, Varrel mengatakan selayaknya masyarakat dengan identitas seksual dan ekspresi gender mayoritas, LGBT memiliki kebutuhan untuk bersosialisasi dan mendapatkan ruang aman dalam aktivitas mereka (Pelangi ditengah Kota: Inklusi bagi LGBT di Perkotaan, 2019). Minoritas di Indonesia dihadapi masalah dengan keterbatasan ruang untuk berdialog dan diskusi. Keterbatasan inilah yang menghambat kaum minoritas untuk menyampaikan informasi, ide serta gagasan dalam melakukan pembukaan diri. Seperti yang terjadi pada kaum Queer dalam LGBTQ+.

Kai Mata merupakan salah satu individu queer. Ia adalah seorang penyanyi dan penulis lagu berkebangsaan Indonesia. Queer adalah seseorang yang tidak mau dikategorikan sebagai gender yang dapat dipasangkan, misalnya laki-laki dan perempuan, homoseksual dan heteroseksual, atau individu yang tidak ingin diberi label berdasarkan identitas seksual mereka. Akun Instagram @Kaimatamusic memiliki 2.821 pengikut di Instagram. Ia juga memasang keterangan dalam bio profilnya yang menggambarkan dirinya dimana ia menyatakan bahwa ia Proudly $L G B T Q+$.

Dalam penelitian ini, penulis tertarik untuk melakukan penelitian mengenai "Self Disclosure Individu Queer Melalui Media Sosial Instagram (Studi Deskriptif Kualitatif pada Akun @Kaimatamusic)". Penulis menemukan hal yang menarik yang perlu dipelajari dan dibahas lebih lanjut. Tujuan penelitian ini diadakan untuk mengetahui bagaimana pembukaan diri Kai Mata melalui akun Instagramnya. Fokus penelitian ini akan terletak pada objek yaitu akun Instagram @kaimatamusic. Dengan mengacu pada teori komunikasi antarpribadi dan konsep self disclosure.

\section{Komunikasi Antarpribadi di Media Sosial}

De Vito (2011) mengatakan, komunikasi antarpribadi adalah bentuk penyampaian informasi oleh satu orang dan penerimaan informasi oleh individu lain atau kelompok kecil, dengan berbagai dampak dan kesempatan untuk memberikan umpan balik secepatnya. Pada hakekatnya, komunikasi antarpribadi merupakan proses pertukaran informasi yang dianggap paling efektif dan prosesnya dapat dilakukan secara sederhana (Harapan, Edi ; Ahmad, Syarwani, 2016). 
Dalam fungsi komunikasi antarpribadi disebutkan bahwa komunikasi tersebut dapat menjalin konsistensi hubungan dengan orang lain yang lebih bermakna dengan orang lain. Terjalinnya suatu hubungan yang bermakna tersebut menandai adanya self disclosure atau keterbukaan diri. Self disclosure merupakan bentuk komunikasi ketika seseorang menyingkapkan sesuatu hal tentang siapa orang tersebut yang biasanya disembunyikan. Berbagai macam aktivitas komunikasi di dalam hubungan antarpribadi berkembang secara online, termasuk perilaku di dalam keterbukaan diri (Loisa, Riris \& Setyanto, Yugih, 2014). Tidwell dan Walther (dikutip Loisa, Riris \& Setyanto, Yugih, 2014) menyatakan bagaimana komunikasi yang dilakukan melalui media digital dapat mempengaruhi ada berapa banyak dan berapa cepat individu memberikan informasi tentang dirinya serta persepsi secara keseluruhan yang dibentuk terhadap satu sama lain.

\section{Self Disclosure}

Keterbukaan diri adalah jenis komunikasi ketika kita mengungkapkan informasi tentang diri kita sendiri yang biasanya kita sembunyikan. Johnson (dalam Supratiknya, 2016) mengatakan bahwa self disclosure adalah memberi atau membagikan kepada orang lain mengenai masa lalu yang pernah sebelumnya dialami oleh individu serta menceritakan kepada orang lain tentang persepsi terhadap sesuatu yang pernah dikatakan atau dilakukan serta perasaan terhadap kejadian-kejadian yang baru saja dialami.

Johnson (dalam Edi Harapan dan Syarwani Ahmad, 2016) mengatakan pembukaan diri dalam komunikasi antarpribadi memiliki dua ciri, yaitu digambarkan sebagai berikut:

Tabel 1. Pembukaan Diri Menurut Johnson

\begin{tabular}{lll}
\hline Ke dalam diri & Ke luar diri \\
\hline $\begin{array}{l}\text { Menyadari diri sendiri, siapa saya, seperti } \\
\text { apa diri saya. }\end{array}$ & $\begin{array}{l}\text { Menyadari orang lain, siapa dia, } \\
\text { seperti apa diri nya. }\end{array}$ \\
\hline+ & + \\
\hline $\begin{array}{l}\text { Menerima diri sendiri, menyadari aneka } \\
\text { kekuatan dan kemampuan diri. }\end{array}$ & $\begin{array}{l}\text { Menerima orang lain, menyadari } \\
\text { aneka kekuatan dan kemampuan diri } \\
\text { orang lain. }\end{array}$ \\
\hline+ & + & \\
\hline $\begin{array}{l}\text { Mempercayai diri untuk menerima dan } \\
\text { mendukung diri, bekerja sama dengan }\end{array}$ & $\begin{array}{l}\text { Dapat dipercaya dengan cara } \\
\text { menerima dan mendukung orang lain, } \\
\text { diri, bersikap terbuka dengan diri. }\end{array}$ & $\begin{array}{l}\text { bekerja sama dengan orang lain, } \\
\text { bersikap terbuka dengan orang lain. }\end{array}$ \\
\hline $\begin{array}{l}\text { Bersikap terbuka kepada orang lain, } \\
\text { membagikan aneka gagasan dan } \\
\text { perasaan diri, dan membiarkan orang lain } \\
\text { tahu siapa diri saya. }\end{array}$ & $\begin{array}{l}\text { Bersikap terbuka bagi orang lain, } \\
\text { gagan dan perasaan serta siapa } \\
\text { orang lain itu. }\end{array}$
\end{tabular}

Bersikap terbuka kepada orang lain + Bersikap terbuka bagi orang lain $=$ Hubungan yang terbuka. 
De Vito menyatakan dalam bukunya yang berjudul "Komunikasi Antarmanusia" (2011), terdapat lima dimensi self disclosure yaitu:

1. Durasi Self Disclosure

Dapat dilihat dari banyaknya individu melakukannya dan berapa lama waktu untuk menyatakan keterbukaan diri tersebut.

2. Kekuatan

Self

Disclosure

Dampak positif dan negatif dari self disclosure, dapat berupa positif dan negatif. Hal tersebut dapat menimbulkan reaksi yang berbeda bagi individu yang mengungkapkan maupun yang mendengarkannya.

3. Kejujuran

Ketepatan self disclosure dibatasi dengan sejauh apa individu mengenai dirinya sendiri. Self disclosure juga tergantung seberapa jujur individu dalam terbuka dengan dirinya.

4. Tujuan

Self

Disclosure

Untuk mengetahui tujuan dari penyingkapan diri itu sendiri sehingga individu dapat mengontrol self disclosure.

5. Keintiman

Terbuka pada hal-hal yang paling intim atau hal-hal yang terletak diantara keduanya.

\section{Queer}

Teori queer berasal dari pernyataan bahwa identitas tidak bersifat kekal dan stabil. Identitas bersifat cair dan dikonstruksi secara sosial. David Halperin mengatakan queer sebagai hal yang bukan normatif jika dikaitkan dengan sesuatu yang sesuai norma yang berkembang di masyarakat. Tidak ada sesuatu yang menonjol yang khusus yang dapat ditunjukkan oleh individu tersebut (Ardhanary Institute, 2015). Maka kemudian disimpulkan, Queer adalah seseorang yang tidak dapat dikategorikan sebagai gender yang bisa dipasangkan, misalnya laki-laki dan perempuan, homoseksual dan heteroseksual, atau seseorang yang tidak mau diberi label berdasarkan identitas seksual yang mereka pilih.

\section{New Media}

Dalam teori CMC (computer-mediated-communication) secara sederhana bisa diartikan sebagai komunikasi yang terjadi antarindividu melalui media computer (Herring dalam Budiargo, 2015). Media komputer merupakan media yang difasilitasi oleh jaringan Internet. Media baru merupakan produk dari komunikasi yang dimediasi internet yang terdapat bersama dengan media digital (Creeber dan Martin, 2009). Kajian media baru awalnya bermula dari teori medium yang merupakan hasil pemikiran Mcluhan yang kemudian digagas oleh Donald Ellis (dalam hamidati dkk, 2011) mengatakan media yang digemari pada suatu masa akan membentuk perilaku dan pikiran individu. Media yang berlaku saat itu juga akan mengubah pola interaksi individu. New Media merupakan media yang menggunakan Internet, media yang menggunakan teknologi, memiliki karakter yang mudah dipindah-pindahkan, memiliki interaktivitas dan dapat berfungsi secara personal maupun secara umum (Mondry, 2008). 
Dhiya Fauziani Hediana, Septia Winduwati: Self Disclosure Individu Queer Melalui Media Sosial Instagram (Studi Deskriptif Kualitatif pada Akun@Kaimatamusic)

\section{Media Sosial}

Media sosial kemudian hadir sebagai bagian dari produk media baru. Nasrullah (2017) menyimpulkan bahwa media sosial adalah sebuah medium di Internet yang memungkinkan pengguna dapat menampilkan dirinya maupun berinteraksi, bekerja sama, membagikan, berkomunikasi dengan pengguna lain dan membentuk hubungan sosial secara online. Media sosial kemudian berkembang melahirkan platformplatform yang memungkinkan penggunanya dapat berinteraksi. Instagram merupakan salah satu bagian dari media sosial. Menurut Bambang (2012), Instagram adalah sebuah aplikasi yang didesain untuk berinteraksi. Media sosial merupakan salah satu dari media baru yang memiliki fungsi untuk mengunggah, mengedit serta mengambil foto dan video atau tempat untuk berbagi informasi terhadap penggunanya. Instagram juga dapat memberikan ide bagi penggunanya dan juga dapat meningkatkan kreatifitas, karena Instagram memiliki fitur yang dapat membuat foto menjadi lebih indah dan menjadi lebih bagus.

\section{Metode Penelitian}

Penelitian ini menggunakan pendekatan kualitatif deskriptif dengan metode yang dipilih adalah studi kasus. Menurut Ruslan (2017), penelitian kualitatif bertujuan untuk mendapatkan pemahaman yang bersifat general terhadap kenyataan sosial dari pandangan individu yang terkait. Pemahaman tersebut tidak dibentuk terlebih dahulu, tetapi didapatkan setelah melakukan analisis terhadap peristiwa sosial yang menjadi fokus penelitian. Data dikumpulkan menggunakan teknik wawancara mendalam, observasi non-partisipan, dokumentasi dan studi kepustakaan. Untuk menganalisis data, peneliti menggunakan teknik reduksi data, penyajian data dan penarikan kesimpulan. Penelitian ini bertujuan untuk mendapatkan gambaran secara sistematis, fakta dan akurat terhadap sifat-sifat objek tertentu. Oleh karena itu, peneliti memilih menggunakan penelitian deskriptif agar dapat menggambarkan secara jelas bagaimana self disclosure yang dilakukan Kai Mata melalui akun Instagram @ kaimatamusic.

\section{Hasil dan Pembahasan}

Hasil penelitian ini menunjukkan bahwa Kai Mata mengenal dirinya dengan baik sehingga ia mampu untuk terbuka kepada orang lain melalui media sosial Instagram mengenai jati dirinya. Kai Mata terbuka dengan membagikan pikiran, perasaan, hasil karya serta aktivitasnya dalam komunitas LGBTQ+. Penerimaan diri serta dukungan penuh dari keluarga dan komunitas LGBTQ+ baik di luar Indonesia ataupun di Indonesia juga membuat Kai Mata mampu percaya diri dan tetap menjalin hubungan dengan status queer di Instagram. Kai Mata sering membagikan aktivitasnya sebagai musisi dan juga aktivis di komunitas LGBTQ+. Melalui ungahannya, ia selalu memberikan caption yang menceritakan ide, gagasan serta perasaan dirinya mengenai hak-hak LGBTQ+ di Indonesia. Meskipun demikian, Kai Mata membatasi untuk dimensi keintiman dengan tidak membagikan informasi pribadi seperti foto dimana ia tinggal, tempat biasa ia pergi makan dan pasangan romantisnya. Hal itu dikarenakan untuk menjaga orang-orang yang bersamanya.

Melalui sikap terbuka kepada orang lain dan sikap terbuka bagi orang lain menciptakan hubungan yang terbuka antara Kai Mata dengan orang-orang yang mengikutinya di Instagram ataupun dengan penggemar musiknya. Berdasarkan penggambaran di atas, Kai Mata dapat mengungkapkan diri terkait identitas 
seksualitasnya, jati dirinya, hasil karyanya, membagikan aktivitasnya dengan komunitas LGBTQ+, mampu menyesuaikan diri dengan cara dapat membalas setiap komentar baik berupa dukungan dan pujian, lebih percaya diri membagikan foto dan video musik yang ia buat sendiri dengan menjadi bagian dari video klip tersebut bersama teman-temannya dari komunitas LGBTQ+, dapat diandalkan karena Kai Mata merasa bahwa dirinya istimewa sehingga dia menjadi bertanggung jawab untuk menyuarakan aspirasi dari teman-teman LGBTQ+ di Indonesia, lebih dapat bersikap positif dan percaya terhadap orang lain ditandai dengan terbuka dengan membagikan perasaan dan pemikiran dia kepada orang lain yang ia temui di media sosial Instagram.

Nasrullah (2017) menyatakan bahwa media sosial adalah medium di Internet yang memungkinkan pengguna menampilkan dirinya maupun berinteraksi, bekerja sama, berkomunikasi dengan pengguna lain dan membangun ikatan sosial secara online. Media sosial merupakan medium baru tempat setiap penggunanya dapat membagikan apapun yang mereka mau tanpa ada batasan yang mengikat atau larangan-larangan sebagaimana yang terjadi pada media konvensional. Menurut Dr. Firman media sosial dapat memberikan pengaruh baik kognitif maupun afektif. Kognisi seseorang akan terbentuk dari yang tidak tahu menjadi tahu. Demikian juga yang namanya gender tidak hanya ada laki laki atau perempuan. Kedua yaitu afeksi, perasaan, faktor emosional, bisa suka ataupun tidak suka. Implikasi dari kognisi dan afeksi, kemudian munculah ke motorik, seseorang bisa menolak, bisa simpati, bisa ikut memperjuangkan sebagai sebuah tindakan yang nyata.

Komunikasi antarpribadi saat ini terjalin melalui jaringan Internet. Komunikasi dapat dilakukan melalui perantara media sehingga menciptakan interaksi tanpa tatap muka. Bentuk komunikasinya berupa menggunakan kolom komentar yang dapat memberikan feedback langsung, Direct Message (DM) di Instagram ataupun Insta Story. Dalam pembahasan tersebut, keterbukaan diri kai Mata dapat berinteraksi menjalin sebuah hubungan secara virtual dengan sangat interaktif, tanpa dibatasi dan dapat dilakukan secara bersamaan. Hilangnya batas ini menjadi sebuah keuntungan untuk kaum queer. Ia bisa berinteraksi dengan siapapun, mengembangkan hubungan sosial di media sosial Instagram.

Self disclosure dapat menjadi keuntungan bagi individu tersendiri. Self disclosure bisa jadi peranan penting untuk mengembangkan hubungan yang terbuka antara dua atau lebih orang. Self disclosure yang tepat maka akan menciptakan rasa percaya diri, kebahagian, komitmen serta mampu bersikap suportif dan positif. Kai Mata hadir ditengah-tengah perdebatan di masyarakat mengenai isu LGBTQ+ yang seringkali dianggap sebagai sesuatu yang negatif dan tabu. Dilihat dari jumlah followers yang dimiliki oleh Kai Mata yang hanya memperoleh sebanyak 2.821 pengikut selama tujuh tahun sejak ia memiliki akun Instagram. Sebagai seseorang yang tergabung dalam komunitas LGBTQ+, Kai Mata hadir membawa hal yang positif dengan keterbukaan dirinya sebagai individu queer yang berprestasi memiliki karya di bidang seni. Melalui keterbukaannya di Instagram, ia berharap masyarakat dapat memandang kaum queer sebagai manusia yang perlu dicintai, diberi dukungan dan bukan sesuatu yang negatif seperti apa yang dikatakan oleh kebanyakan orang sebagai seorang pendosa. Hal ini menunjukkan bahwasannya masih kurangnya dukungan dari masyarakat Indonesia terkait isu komunitas LGBTQ+.

Pada penelitian ini Kai Mata menunjukkan sikap positif dalam keterbukaan dirinya melalui media sosial Instagram dengan sering membagikan aktivitasnya terkait untuk meningkatkan kesadaran mengenai keberadaan kaum queer dan hak-hak LGBTQ+ yang masih didiskriminasi di Indonesia. Ia juga membagikan hasil karya 
musiknya, gagasan serta pemikirannya yang ia tuangkan dalam caption unggahan fotonya di akun Instagramnya. Meskipun dalam keterbukaan dirinya, Kai Mata tidak menyingkapkan hal yang intim seperti tidak membagikan foto keluarga dan kekasihnya. Kai Mata tetap menunjukkan sikap supportifnya dengan cara membalas setiap dukungan dan ujaran kebencian yang didapatkannya di akun Instagram.

\section{Simpulan}

Berdasarkan hasil penelitian yang telah dilakukan oleh peneliti, maka kesimpulan yang didapatkan yaitu:

1. Keterbukaan Diri (Self disclosure) dalam hubungan sosial dengan orang lain. Kai Mata dapat mengungkapkan diri dengan pada identitas seksualnya dan membagikan hasil karya berupa video musik yang mengandung unsur LGBTQ+, gagasan, aktivitas mengenai LGBTQ+ dan sikap yang terbuka dengan orang lain di Instagram.

2. Keterbukaan diri (Self disclosure) Kai Mata melalui sosial media dapat dilakukan karena adanya penerimaan serta dukungan penuh yang ia dapatkan dari keluarga dan teman-teman LGBTQ+ pengguna Instagram.

3. Kai Mata membagikan perasaan, serta gagasan mengenai dirinya serta hak-hak LGBTQ+ di Indonesia melalui postingan foto dan video, Instastory di Instagram.

4. Self disclosure merupakan bagian dari cara Kai Mata berkomunikasi dan menunjukkan keberaniannya dalam menyampaikan pesan-pesan mengenai dirinya. Namun demikian, ada batasan dalam keterbukaan dirinya yakni dirinya tidak membagikan informasi pribadi terkait pasangannya, foto dimana ia tinggal dan tempat biasa ia makan. Media baru saat ini hadir sebagai medium yang sangat interaktif untuk melakukan komunikasi.

\section{Ucapan Terimakasih}

Peneliti ingin mengatakan terimakasih atas kerjasamanya kepada para narasumber dalam penelitian ini yang sudah bersedia dan meluangkan waktu untuk mendukung penelitian ini. Terimakasih kepada kedua orang tua. Kemudian untuk teman-teman peneliti yang sangat baik, peneliti ingin mengucapkan terimakasih atas keikutsertaannya dalam membantu serta mendukung peneliti selama melakukan penelitian ini.

\section{Daftar Pustaka}

A. Supratiknya,. (2016). Tinjauan Psikologis Komunikasi Antarpribadi. Yogyakarta: Kanisius.

Ardhanary Institute. (n.d). My Body, My Sexuality, My Rights. Memahami Teori Queer. November 11, 2019. http://ardhanaryinstitute.org/index.php/2015/11/15/memahami-teori-queer-5/

DeVito, Joseph. (2011). Komunikasi Antarmanusia (ed. 5). Tangerang: Karisma Publishing Group.

Gainau, Maryam. (2017). Keterbukaan Diri (Self Disclosure) Siswa Dalam Perspektif Budaya dan Implikasinya Bagi Konseling. Februari, 4 2017. Terarsip di: http://puslit2.petra.ac.id/ejournal/index.php/jiw/article/viewFile/17061/17024 
Hamidati, dkk. (2011). Komunikasi 2.0: Teori dan Implikasi. Yogyakarta: Mata padi Pressindo.

Harapan, Edi \& Ahmad, Syarwani. (2016). Komunikasi Antarpribadi: Perilaku Insani Dalam Organisasi Pendidikan. Depok: PT. Rajagrafindo Persada.

Loisa, Riris \& Setyanto, Yugih. (2014). Penyingkapan Diri Melalui Internet DI Kalangan Remaja (Studi Komunikasi Antarpribadi). Juni, 3 2014. Terarsip di: https://journal.untar.ac.id/index.php/komunikasi/article/view/38/20

Mondry. (2008). Pemahaman Teori dan Praktik Jurnalistik. Bogor: Ghalia Indonesia Mukhtar. (2013). Metode Penelitian Deskriptif Kualitatif. Jakarta : GP Press Group

Nasrullah, Rulli Dr. (2017). Media Sosial: Perspektif Komunikasi, Budaya, dan Sosioteknologi. Bandung: PT. Remaja Rosdakarya.

Ruslan, Rosady. (2017). Metode Penelitian Public Relations dan Komunikasi. Jakarta : PT Raja Grafindo Persada. 